\title{
PENGGUNAAN PERJANJIAN BAKU DALAM TRANSAKSI BISNIS MENURUT HUKUM ISLAM
}

\author{
Abdul Karim Munthe \\ Program Magister Fakultas Hukum Universitas Indonesia \\ Kampus FHUI Gedung A Lantai 2 Depok 16424, Jawa Barat \\ E-mail: karimmunthe34@gmail.com
}

\begin{abstract}
The Use of Standard Contract in Business Transactions According to Islamic Law. Contract is the basic point of a transaction, including the transactions in Islamic economic. The rapid development of Islamic economics forcesan adaptation of economic contract in accordance with the development of society. Standard contract is a common form for printing an agreement. It is a contract that has been set unilaterally by the company. Theoretically, standard contract is accepted both in positive law in Indonesia and Islamic law (based on habitual or 'urf. Standard contract should consider legal protection for both parties, especially consumers. Standard contracts should create justice, equality and prioritize the concept of khiyar.
\end{abstract}

Keywords: standard contract, justice, equality, khiyar

\begin{abstract}
Abstrak: Penggunaan Perjanjian Buku dalam Transaksi Bisnis Menurut Hukum Islam. Perjanjian meruapakan ruh dari sebuah transaksi, termasuk transaksi ekonomi Islam.Semakin pesatnya perkembangan ekonomi Islam memaksa perjanjian ekonomi harus disesuaikan dengan perkembangan masyarakat. Perjanjian baku adalah bentuk perubahan perjanjian biasa yang selama ini dikenal. Perjanjian baku merupakan perjanjian yang telah ditetapkan sepihak oleh perusahaan. Secara teori perjanjian baku dapat diterima baik dalam sistem hukum Indonesia maupun dalam sistem hukum Islam, berdasarkan kebiasaan atau 'urf. Perjanjian baku harus memperhatikan perlindungan hukum bagi kedua belah pihak, khususnya konsumen. Perjanjian baku agar menciptakan keadilan dan kesetaraan harus memperhatikan konsep khiyâr.
\end{abstract}

Kata kunci: perjanjian baku, keadilan, kesetaraan, khiyâr

\section{Pendahuluan}

Perkembangan usaha syariah terus mengalami peningkatan. Pertumbuhan ini tidak lain karena dukungan pemerintah maupun lembaga yang berkaitan dengan keuangan semakin meningkat. Sosialisasi yang dilakukan pemerintah cukup memberi dampak positif dalam perkembangan ekonomi syariah. Dari segi politik hukum, ekonomi syariah dalam tataran undang-undang sudah mulai meningkat. Tercatat sampai sekarang sudah ada beberapa undang-undang yang terkait dengan ekonomi syariah. Di antaranya adalah Undang-undang Nomor 21 Tahun 2008 tentang Perbankan Syariah, Undangundang Nomor 19 Tahun 2008 tentang Surat Berharga Syariah Negara, dan yang paling terbaru adalah Undangundang Nomor 40 Tahun 2014 tentang Perasuransian.

Hukum ekonomi syariah merupakan bagian dari sistem hukum Islam yang mengatur hubungan antar

Naskah diterima: 7 Desember 2014, direvisi: 29 Februari 2015, disetujui untuk terbit: 05 Maret 2015. manusia (dalam bahasa Arab disebut mu'âmalah). Sistem hukum Islam secara umum dapat kita bagi ke dalam dua kategori, yaitu ibadah dan muamalah. Dalam bidang muamalah terdapat dua ketegori yaitu, mu'âmalah al-khâs termasuk dalam kategori ini adalah transaksi perdagangan atau bisnis. Kedua, adalah mu'âmalah al-âm termasuk dalam kategori ini adalah pidana (jinâyah), tata negara (siyâsah), hukum acara.

Dasar hukum dari adanya suatu bisnis atau perdagangan adalah dengan adanya perjanjian yang mengikat antara para pihak. Perjanjian ini disebut dengan perikatan atau al-'aqd (dalam istilah Arab kemudian diadopsi dalam bahasa Indonesia dengan akad). Hukum perikatan Islam menurut Tahir Azhari merupakan seperangkat kaidah hukum yang bersumber dari Alquran, Sunah, dan al-Ray (ijtihad) yang mengatur hubungan antara dua orang atau lebih mengenai suatu benda yang dihalalkan menjadi objek suatu transaksi. ${ }^{1}$

${ }^{1}$ Gemala Dewi, Aspek Hukum dalam Perbankan dan Perasuransian di Indonesia, Edisi Revisi cet. Ke-3, (Jakarta: Kencana, 2006), h. 9. 
Dalam konteks yang lebih luas setiap kesepakatan kerja sama baik dalam bentuk transaksi maupun dalam bentuk penyertaan modal juga merupakan bagian dari perikatan. Atas dasar itu dapat kita katakan bahwa sebuah perjanjian merupakan ruh dari setiap bisnis. Perkembangan ekonomi, serta perlunya efisiensi dalam setiap kegiatan bisnis memengaruhi perkembangan penggunaan perjanjian. Hampir setiap kegiatan yang langsung berhubungan dengan orang yang banyak, perusahaan selalu menggunakan perjanjian yang telah dibuat sepihak oleh perusahaan, perjanjian ini biasa disebut dengan perjanjian baku.

Perjanjian yang telah disediakan sepihak oleh perusahaan ini mengakibatkan pihak konsumen tidak memiliki kesempatan untuk melakukan negosiasi atau tawar menawar ketika melakukan transaksi. Permasalahannya adalah bagaimana pandangan hukum Islam terhadap perjanjian baku?

Atas dasar latar belakang tersebut penulis melakukan penelitian yuridis normatif dan komparatif yuridis terhadap kedudukan perjanjian baku dalam perspektif hukum perdata dan hukum Islam. Sumber hukum yang digunakan dalam penelitian ini adalah buku III KUH Perdata tentang perikatan, Undang-undang Nomor 8 tahun 1999 tentang Perlindungan Konsumen, Peraturan Otoritas Jasa Keuangan Nomor 1/POJK.07/2013 tentang Perlindungan Konsumen Sektor Jasa Keuangan dan fatwa Dewan Syariah Nasional, dan KHES.

\section{Keadilan dan Kebebasan Berkontrak: Tinjauan 'urf}

Pembinaan hukum Islam yang dilakukan Nabi Saw. kepada umatnya adalah untuk (1) menjelaskan tujuan hukum Islam adalah untuk kemaslahatan dan rahmat untuk umat; (2) menjelaskan bahwa hukum Allah tidak akan menyulitkan umat manusia; (3) dalam memberikan penjelasannya, Nabi Saw. melakukannya dengan bahasa umatnya sendiri. ${ }^{2}$ Secara umum dari tujuan hukum Islam hadir adalah untuk menciptakan kemaslahatan serta menghindari dari kemafsadatan.

Hukum Islam sebagai hukum agama memiliki perbedaan dengan hukum di luar Islam. Pembentukan hukum Islam berdasarkan pada Alquran dan Hadis. Kedua sumber ini merupakan sumber primer dalam pembentukan hukum Islam. Tidak ada satu peraturanpun dalam Islam yang boleh bertentangan dengan Alquran dan Hadis. Karena dalam politik

${ }^{2}$ Amir Syarifuddin, Meretas Kebekuan Ijtihad: Isu-isu Penting Hukum Islam Kontemporer di Indonesia, Cet. Ke-2. (Jakarta: Ciputat Press, 2005), h. 128. hukum Islam, setiap hukum yang dibentuk berdasarkan Alquran dan Hadis akan menghasilkan hukum yang berkeadilan. Beda halnya kalau dalam pembentukan hukum yang diambil dari kebijakan pemerintah maka ada dua kemungkinan bisa adil dan bisa juga zalim. ${ }^{3}$

Tabel Konfigurasi Politik dan Karakter Hukum

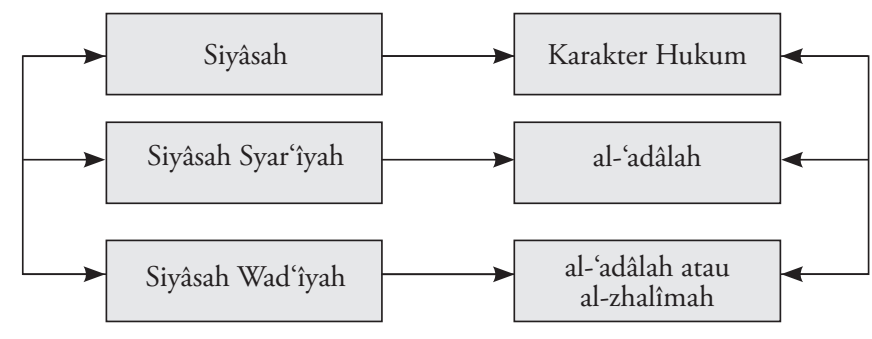

Dalam pembentukan hukum Islam dalam konteks Indonesia, khususnya yang berkaitan dengan ekonomi syariah diperlukan pengembangan metode dalam menciptakan hukum yang berkeadilan. Dalam kajian penemuan hukum Islam untuk menciptakan hukum yang berkeadilan harus merujuk kepada hukum yang telah ditetapkan oleh Allah Swt., sebagaimana telah penulis jelaskan di atas. Keadilan menurut Kasani merupakan salah satu ketakwaan yang paling baik dan salah satu kewajiban paling penting setelah iman kepada Allah Swt. ${ }^{4}$

Keadilan merupakan tali yang menyatukan masyarakat dan menjadikan mereka bersaudara. Kita harus berdiri kokoh untuk mendirikan keadilan walaupun mungkin itu mengganggu kepentingan kita. ${ }^{5}$ Keadilan dalam hukum Islam terkait dengan ekonomi harus bisa menciptakan kesejahteraan bagi masyarakat itu sendiri, baik secara kelompok maupun secara individu. Sebagaimana kita jelaskan di atas, hukum Islam yang berkeadilan tidak lepas dari sumber hukum Islam utama, yaitu Alquran dan Hadis.

Untuk menciptakan hukum Islam yang berkeadilan ada dua model pendekatan dalam pemahaman syariah, ${ }^{6}$ yaitu pemahaman secara kebahasaan. Pemahaman seperti ini adalah melihat hukum Islam dari segi luarnya saja, yaitu melihat pada aspek kebahasaan Alquran maupun Hadis itu sendiri. Kedua adalah pendekatan maqâshid al-syarî‘ah, yaitu pendekatan yang digunakan

${ }^{3}$ Abdul Halim, Politik Hukum Islam di Indonesia: Kajian Posisi Hukum Islam dalam Politik Hukum Pemerintahan Orde Baru dan Era Reformasi, (Jakarta: Badan Litbang dan Diklat Departemen Agama RI, 2008), h. 48.

${ }^{4}$ Muhammad Muslehuddin, Filsafat Hukum Islam dan Pemikiran Orientalis: Studi Perbandingan Sistem Hukum Islam, terj. Yudian Wahyuni, (Yogyakarta: Tiara Wacana Yogya, 1991), h. 81.

${ }_{5}^{5}$ Muhammad Muslehuddin, Filsafat Hukum Islam dan Pemikiran Orientalis: Studi Perbandingan Sistem Hukum Islam, terj. Yudian Wahyuni, h. 81

${ }^{6}$ Kata pengantar penulis dalam buku Nasrun Haroen, Ushul Fiqh 1, cet. Ke-2, (Jakarta: PT. Logos Wacana Ilmu, 1997), h. xi 
dalam hal penerapan hukum. Pendekatan ini sudah melihat pada aspek yang ada dibalik syariat itu sendiri. Metode yang digunakan dalam pendekatan ini salah satunya adalah "urf.

'Urf dalam konteks maqâshid al-syarîah dijadikan sebagai legitimasi terhadap kebiasaan masyarakat. Keadilan dalam Islam adalah mewujudkan maqâshid al-syarîah, oleh imam Ghazali melindungi agama, jiwa, akal, keturunan dan harta. ${ }^{7}$ Keberadaan 'urf sebagai sebuah pendekatan dalam kajian hukum Islam bisa dikatakan sudah cukup lama ada. Pembahasan 'urf sering kali disandingkan dengan al-'âdah. 'Urf berarti kebiasaan mayoritas kaum, baik dalam perkataan maupun perbuatan. ${ }^{8}$ Sedangkan al-âdah adalah suatu kebiasaan masyarakat yang dilakukan berulang-ulang. Kata berulang-ulang inilah yang membedakan 'urf dengan 'âdah."

Dalam melihat penerapan suatu hukum, kedudukan urfatau 'âdah menjadi penting dalam penetapan hukum Islam. Sebagaimana dalam kaidah dikatakan al-âdah al-mubakkamah, ${ }^{10}$ (adat itu menjadi dasar hukum). 'urf dapat dijadikan sebagai dasar hukum ketika hukum tidak berbicara terkait permasalahan yang dihadapi. Akan tetapi dengan catatan bahwa 'urf tersebut tidak boleh bertentangan dengan prinsip-prinsip syariah lainnya.

Prinsip kebebasan berkontrak merupakan prinsip umum $^{11}$ yang tidak bisa ditawar-tawar dalam setiap perjanjian, baik itu dalam perjanjian Islam. Perjanjian yang di dalamnya terdapat unsur paksaan maka perjanjian tersebut dapat dibatalkan. Keberadaan prinsip ini diakui dalam KUH Perdata pasal 1233 dinyatakan bahwa "tiap-tiap perikatan dilahirkan baik karena persetujuan, baik karena undang-undang". Pada ayat ini jelas bahwa setiap orang tidak boleh dipaksa oleh siapapun untuk melakukan perjanjian. Pada pasal 1320

\footnotetext{
${ }^{7}$ Abû Hamîd al-Ghazalî, al-Mustasfá, (Beirut: Dâr al-Kutûb al'Ilmîyah, 1413 H), h. 174.

${ }^{8}$ Dalam bahasa Arabnya, عادة جمهور قوم فن قول أو فعل atas dasar ini pula Mustafa al-Zarqa mengatakan bahwa adat bagian dari urf. Ma'ruf Amin, Fatwa Dalam Sistem hukum Islam, Cet. Ke-3, (Jakarta: eLSAS, 2011), h. 210.

${ }_{9}$ Amir Syarifuddin, Ushul Figh Jilid 2, Cet. Ke-2, (Jakarta: PT. Logos Wacana Ilmu, 2001), h. 364.

${ }^{10}$ Kaidah ini merupakan bagian dari lima kaidah yang disepakati. Kaidah ini berdasarkan firman Allah dalam Q.s. al-A'râf [7]: 99

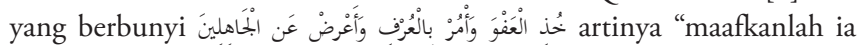
dan suruhlah berbuat makruf”. D́alam hadis juga dijelaskan bahwa

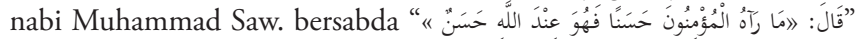
Muhammad Yasin bin 'Isa al-Fadanî, ál-Fawât-id al-Janiyah, (Beirut: Dâr al-Mahjah al-Baydha, 2008), h. 266.

${ }^{11}$ Sutan Remy Sjahdeini, Kebebasan Berkontrak dan Perlindungan yang Seimbang Bagi Para Pihak dalam Perjanjian Kredit Bank di Indonesia, (Jakarta: Institut Bankir Indonesia, 1992), h. 18.
}

dijelaskan bahwa "untuk sahnya suatu perjanjian diperlukan empat syarat: (1) sepakat mereka yang mengikatkan dirinya; (2) kecakapan untuk membuat suatu perikatan; (3) suatu hal tertentu; (4) suatu sebab yang halal;

Kompilasi Hukum Ekonomi Syariah (KHES) mengatur asas dalam melakukan perjanjian. ${ }^{12}$ Prinsip ini berhubungan dengan keadilan dan kebebasan para pihak dalam melukakan transaksi. Pasal 21 huruf a mengatur bahwa: "ikhtiyarî/sukarela; setiap akad dilakukan atas kehendak para pihak, terhindar dari keterpaksaan karena tekanan salah satu pihak atau pihak lain". Pada huruf f diatur bahwa "taswîyah/kesetaraan; para pihak dalam setiap akad memiliki kedudukan yang setara, dan mempunyai hak dan kewajiban yang seimbang."

Dari dua ketentuan di atas jelas bahwa dalam KHES kebebasan berkontrak dicerminkan atas tidak adanya paksaan para pihak, dan isi yang diatur dalam perjanjian tersebut harus setara dan mempunyai hak dan kewajiban yang seimbang.

Ruang lingkup asas kebebasan berkontrak bisa kita lihat sebagai berikut: (1) kebebasan untuk membuat atau tidak membuat perjanjian; (2) kebebasan untuk memilih pihak dengan siapa ia membuat perjanjian; (3) kebebasan untuk menentukan atau memilih causa dari perjanjian yang akan dibuatnya; (4) kebebasan untuk menentukan objek perjanjian; (5) kebebasan untuk menentukan bentuk suatu perjanjian; dan (6) kebebasan untuk menerima atau menyimpangi ketentuan undang-undang yang bersifat opsional. ${ }^{13}$

Perlu diketahui bahwa walaupun sistem hukum nasional dan sistem hukum Islam mengakui akan kebebasan berkontrak, secara hukum masih ada pembatasan yang harus diperhatikan. Dalam KUH Perdata pembatasan itu bisa kita lihat dari ketentuan pasal 1320 yang membatasi subjek yang melakukan kontrak, serta isi kontrak yang tidak boleh bertentangan dengan norma dan hukum yang berlaku. Serta objek tersebut dijelaskan dalam pasal 1332 harus bernilai harus bernilai ekonomi.

Selain yang diatur dalam KUH Perdata di atas, hukum Islam juga memberikan batasan lain terkait dengan kebebasan berkontrak. Ekonomi Islam sebagai

${ }^{12}$ Bandingkan dengan penjelasan dalam buku Gemala Dewi, dkk., Hukum Perikatan Islam di Indonesia, h.30-38. Dijelaskan bahwa asas-asas perikatan dalam Islam ada tujuh yaitu: (1) asas ilahiah; (2) asas kebebasan (al-hurrîyah); (3) asas persamaan atau kesetaraan (almusawwah); (4) asas keadilan (al-áâlah); (5) asas kerelaan (al-ridhá); (6) asas kejujuran dan kebenaran (al-shidq); dan (7) asas tertulis (alkitâbah).

${ }^{13}$ Remy Sjahdeini, Kebebasan Berkontrak dan Perlindungan yang Seimbang..., h. 47. 
sebuah sistem ekonomi memiliki perbedaan dengan sistem ekonomi lainnya. Yusuf al-Qardhawi mengatakan bahwa yang membedakan antara ekonomi Islam dengan ekonomi lainnya adalah ekonomi Islam dibangun di atas landasan etika dan moral. Nilai merupakan bagian dari karakteristik syariat Islam dan keunikan peradaban Islam. ${ }^{14}$ Ada tujuh hal yang apabila terdapat dalam akad maka transaksi tersebut diharamkan, ketujuh hal itu adalah: (1) di dalamnya terdapat riba; (2) di dalamnya terdapat unsur gharar, ${ }^{15}$ (3) di dalamnya terdapat unsur kezhaliman; (4) di dalamnya terdapat maysir (judi); (5) yang diperjualbelikan (transaksikan) adalah barang yang diharamkan; (6) maksiat; (7) di dalamnya ada risywah; ${ }^{16}$

Pembatasan kebebasan di atas bukan berarti menghilangkan kebebasan itu sendiri. Kebebasan di sini bukan berarti semuanya harus sama. Perbedaan posisi dan kondisi sudah merupakan sunnatullâh yang tidak bisa dihilangkan. Yang terpenting adalah bagaimana persamaan ini bisa diakses secara bersama oleh setiap pihak. Termasuk dalam kontrak baku ini adalah konsumen.

Dari penjelasan di atas dapat dipahami bahwa kebebasan berkontrak bukan berarti bebas menentukan isi kontraknya. Ada pakem-pakem yang harus ditaati dalam pembentukan kontrak, khususnya terkait dengan pelarangan praktik perjanjian yang mengandung unsur riba dan merugikan orang lain. Setiap perjanjian harus saling memberikan manfaat kepada kedua belah pihak.

${ }^{14}$ Eva Zulfa Nailufar, Pengupahan, h. 13. Keunikan ini bisa kita lihat bagaimana perubahan hukum Islam dari halal menjadi haram, dari sunah menjadi makruh dan kebolehan (jaiz). Perubahan hukum ini tidak lepas dari keberadaan etika dan moral, baik agama maupun masyarakat dalam penentuan hukum Islam.

15 Gharar dalam pengertiannya adalah sesuatu yang tidak diketahui secara pasti, seperti membeli ikan yang masih di dalam kolam. Dan praktik seperti ini diharamkan oleh ulama dengan pertimbangan hadis yang diriwayatkan oleh imam Muslim, Tirmidzi, Abu Daud, Nasai yang bersumber dari sahabat Abu Hurairah, yang mengatakan Rasulullah Saw. melarang jual beli gharar. Dr. Musthafa Dib Bugha mengatakan bahwa ulama fikih membagi gharar ke dalam tiga bagian, yaitu, pertama, gharar katsîr, kedua, gharar yasîr, dan ketiga, gharar mutawassith. (Musthafa Dib Bugha, Buku Pintar transaksi Syariah), h. 89. Sedangkan ulama Malikiah menjelaskan bahwa tidak semua gharar itu diharamkan ada yang masih dimaafkan sebagaimana dijelaskan oleh Husain hamid Hisan, apabila ada tiga unsur berikut, yaitu: 1) gharar-nya yasirr; 2) tidak diniatkan/tidak dimaksudkan; 3) dalam keadaan darurat. Lihat Nandi Rahman, Asuransi dalam Pandangan Islam, (Jakarta: Lembaga Pers Bekasi, 2003), h. 8

16 Lihat, Fatwa Dewan Syariah Nasional NO: 21/DSNMUI/X/2001, tentang Pedoman Umum Asuransi Syariah, dalam bagian pertama dalam putusan.

\section{Penggunaan Perjanjian Baku dalam Transaksi Bisnis Menurut Hukum Islam}

Perjanjian dalam bahasa Arab disebut dengan al'ahd atau al-wa'd. ${ }^{17}$ Selain itu perjanjian (akad) disebut juga dengan al-aqd yang secara etimologi berarti perikatan, perjanjian dan permufakatan. ${ }^{18}$ Kata al-aqd terdapat dalam Q.s. al-Mâ-idah [5]: ayat 1. Menurut Faturahman Djamil, istilah al-aqd ini dapat disamakan dengan istilah verbintesis dalam $\mathrm{KUH}$ perdata. Sedangkan istilah al-ahd dapat disamakan dengan istilah perjanjian atau overeenkomst, yaitu suatu pernyataan dari seseorang untuk mengerjakan atau tidak mengerjakan sesuatu yang tidak berkaitan dengan orang lain. Istilah ini terdapat dalam Q.s. Ali Imran [3]: 76, yaitu "sebenarnya siapa yang menepati janji yang dibuatnya dan bertakwa, maka sesungguhnya Allah menyukai orang-orang yang bertakwa." 19

Dalam KHES pasal 20 ayat (1) dijelaskan bahwa yang dimaksud dengan Akad adalah "kesepakatan dalam suatu perjanjian antara dua pihak atau lebih untuk melakukan dan/atau tidak melakukan perbuatan hukum tertentu."

KUH Perdata dalam pasal 1313 menjelaskan bahwa yang dimaksud dengan perjanjian adalah, "suatu perbuatan dengan mana satu orang atau lebih mengikatkan dirinya terhadap satu orang lain atau lebih."Sedangkan Soebekti memberikan defenisi, bahwa perjanjian adalah suatu peristiwa di mana seseorang berjanji untuk melaksanakan sesuatu hal. ${ }^{20}$

Dari defenisi di atas penulis memberi defenisi bahwa yang dimaksud dengan perjanjian adalah suatu pernyataan yang dibuat oleh orang cakap hukum ${ }^{21}$ yang memuat kesepakatan bersama (hak dan kewajiban) antara kedua belah pihak atau lebih, yang mengikat terhadap suatu hal tertentu. Unsur-unsur dari sebuah perjanjian adalah, (a) orang yang melakukan perjanjian;

\footnotetext{
${ }^{17}$ Baca lebih lanjut al-wa'd ketika menjadi teori dalam sebuah akad transasi. Jaih Mubarok dan Hasanuddin, "Teori al-Wa'd dan Implementasinya dalam Regulasi Bisnis Syariah", dalam Jurnal Ahkam, Jurnal Ilmu Syariah, Vol. XI, No. 2, Juli 2012, h. 240.

${ }_{18}$ AH. Azharudin Latif, Fiqh Muamalat, (Jakarta: UIN Jakarta Press: 2005), h. 59.

19 Gemala Dewi, dkk, Hukum Perikatan Islam di Indonesia, (Jakarta: Kencana, 2007), h. 45.

${ }^{20}$ Subekti, hukum Perjanjian, Cet ke-19, (Jakarta: Intermasa, 2002), h. 1.

${ }^{21}$ Yang dimaksud degan cakap hukum adalah mereka yang telah mencapai usia 21 tahun, tidak dalam pengampuan, dan istri, namun ketentuan istri tidak cakap hukum sudah tidak berlaku lagi sebab, dengan lahirnya UU No. 1 Tahun 1974 memberi derajat yang sama antara suami dan istri. Oleh karena itu istri dapat melakukan perbuatan hukum tanpa harus meminta izin dari suami. Selain itu orang dinyatakan pailit juga dikategorikan sebagai tidak cakap hukum. Lihat pasal 1330 KUH Perdata.
} 
(b) isi kesepakatan (hak dan kewajiban); dan (c) objek yang diperjanjikan;

Kontrak baku, kontrak standar atau kontrak adhesi adalah beberapa istilah yang digunakan terhadap perjanjian yang seluruh klausul-klausulnya sudah dibakukan oleh pemakainya dan pihak yang lain pada dasarnya tidak mempunyai peluang untuk merundingkan atau minta perubahan. ${ }^{22}$

Perjanjian baku pada umumnya telah tercetak (boilerplate) sehingga pihak lain tidak memiliki kesempatan untuk menegosiasi, pilihan yang ada adalah mengambil kontrak tersebut atau meninggalkannya, ${ }^{23}$ hal yang senada juga diutarakan oleh Hondius. ${ }^{24}$ Yang belum dibakukan hanya terkait beberapa hal yaitu seputar objek yang ditransaksikan dan besaran biaya yang harus ditanggung. ${ }^{25}$

Di tengah bisnis yang semakin pesat diperlukan kontrak yang baku untuk mengefisiensikan biaya, tenaga, dan waktu ${ }^{26}$ dalam perjalanan bisnis. Banyak contoh perjanjian yang bisa kita lihat penggunaan kontrak baku seperti tiket pesawat, kredit bank, jual beli, asuransi, dan lain-lain.

Ciri-ciri kontrak baku menurut Mariam Badrulzaman, yaitu: (a) isi ditetapkan secara sepihak oleh pihak yang posisi (ekonominya) kuat; (b) masyarakat (debitur) sama sekali tidak ikut bersama-sama menentukan isi perjanjian; (c) terdorong oleh kebutuhannya, debitur terpaksa menerima perjanjian itu; (d) bentuknya tertulis; dan (e) dipersiapkan secara massal dan kolektif. ${ }^{27}$

Secara khusus perjanjian baku memiliki prinsip tambahan di luar perjanjian biasa. Munir Fuadi menjelaskan ada empat $(4)^{28}$ prinsip yang harus diperhatikan dalam kontrak baku yaitu: (a ) Prinsip kesepakatan kehendak dari para pihak. Kesepakatan sebagai dasar sahnya perikatan tetap menjadi penentu sah atau tidaknya kontrak tersebut. Sebagaimana dijelaskan

${ }^{22}$ Sutan Remy Sjahdeini, Kebebasan Berkontrak dan Perlindungan Yang Seimbang Bagi Para Pihak dalam Perjanjian Kredit Bank di Indonesia, (Jakarta: Institut Bankir Indonesia, 1993), h. 66.

${ }^{23}$ Munir Fuady, Hukum Kontrak (Dari Sudut Pandang Hukum Bisnis), Buku Kedua, (Jakarta: PT. Citra Aditya Bakti, 2003), h. 76.

${ }^{24}$ Salim HS, dkk., Perancangan Kontrak dan Momerandum of Understanding (MoU), (Jakarta: Sinar Grafika, 2007), h. 70.

${ }^{25}$ Sutan Remy Sjahdeini, Kebebasan Berkontrak dan Perlindungan yang Seimbang Bagi Para Pihak dalam Perjanjian Kredit Bank di Indonesia, h. 66.

${ }^{26}$ Salim HS, dkk. Perancangan Kontrak dan Momerandum of Understanding $(\mathrm{MoU})$, h. 73.

27 Salim HS, dkk. Perancangan Kontrak dan Momerandum of Understanding (MoU), h. 70-71.

${ }^{28}$ Munir Fuady, Hukum Kontrak (Dari Sudut Pandang Hukum Bisnis), Buku Kedua, h. 84-85. dalam pasal 1320 KUH Perdata yang menyatakan perjanjian yang sah adalah adanya kesepakatan dari kedua belah pihak. Walaupun kontrak baku dibuat oleh salah satu pihak saja, unsur kesepakatan harus dapat dipenuhi dalam kontrak baku tersebut. Kesepakatan itu dapat ditandai dengan ditandatanganinya kontrak tersebut ${ }^{29}$ atau dengan cara serah terima barang yang ditransaksikan; (b) Prinsip asumsi risiko dari para pihak. Adanya asumsi resiko dalam perjanjian tidak dilarang. Artinya apabila salah satu pihak bersedia menanggung resiko tersebut, ketika resiko tersebut terjadi maka yang menyatakan bersedia tersebut harus menanggung resiko tersebut; ${ }^{30}$ (c) Prinsip kewajiban membaca (duty to read). Prinsip kewajiban membaca oleh konsumen yang dianut oleh sistem negara common law seperti Amerika juga harus diperhatikan konsumen yang ada di Indonesia. Disiplin ilmu hukum juga mengajarkan bahwa setiap pihak wajib membaca kontrak yang mereka tanda tangani. Tanda tangan yang dibubuhkan dalam kontrak tersebut adalah tanda kalau mereka telah membaca sepenuhnya kontrak yang mereka sepakati; ${ }^{31} \mathrm{~d}$. Prinsip kontrak mengikuti kebiasaan; Kontrak sebagai role yang mengatur apa yang harus dilakukan dan tidak boleh dilakukan para pihak bukan berarti apa yang tidak dicantumkan dalam kontrak boleh dilakukan atau tidak boleh dilakukan. Ada prinsip kebiasaan juga yang mengikat para pihak dalam perjanjian. ${ }^{32}$

\section{Keabsahan Perjanjian Baku Menurut Syariah}

Keabsahan kontrak baku sebenarnya tidak perlu dipersoalkan lagi, sebab, kontrak baku telah ada sejak 80 tahun yang lalu. ${ }^{33}$ Walaupun demikian perdebatan tentang keabsahan kontrak baku tidak bisa dilupakan begitu saja, sebab, hal ini berkaitan dengan perbaikan peraturan perundang-undangan khususnya yang berkaitan dengan penggunaan kontrak baku.

Ahli hukum berbeda pandangan dalam menilai keabsahan kontrak baku. Negara yang umumnya bersistem Eropa Kontinental berbeda pandangan dalam menilai keabsahannya dengan argumentasinya masing-

\footnotetext{
${ }^{29}$ Munir Fuady, Hukum Kontrak (Dari Sudut Pandang Hukum Bisnis), Buku Kedua, h. 84.

${ }^{30}$ Munir Fuady, Hukum Kontrak (Dari Sudut Pandang Hukum Bisnis), Buku Kedua, h. 84.

${ }^{31}$ Munir Fuady, Hukum Kontrak (Dari Sudut Pandang Hukum Bisnis), Buku Kedua, h. 85.

${ }^{32}$ Munir Fuady, Hukum Kontrak (Dari Sudut Pandang Hukum Bisnis), Buku Kedua, h. 85.

${ }^{33}$ Sutan Remy Sjahdeini, Kebebasan Berkontrak dan Perlindungan yang Seimbang Bagi Para Pihak dalam Perjanjian Kredit Bank di Indonesia, h. 70.
} 
masing. Sluijter mengatakan bahwa kontrak baku bukan perjanjian. Baginya kontrak yang dibuat oleh perusahaan adalah undang-undang swasta. Dengan bahasa yang berbeda Pitlo mengatakan kontrak baku adalah perjanjian paksa. ${ }^{34}$

Bagi yang mendukung sahnya kontrak baku berdasarkan alasan fiksi adanya kemauan dan kepercayaan yang mengikatkan dirinya pada kontrak baku tertsebut, pendapat ini diutarakan oleh Stein. ${ }^{35}$ Pendapat lain yang mendukung keabsahan kontrak baku diutarakan oleh Hondius yang berpendapat bahwa kontrak baku telah menjadi kebiasaan yang berlaku di masyarakat dan lalu lintas bisnis. ${ }^{36}$

Asser Ruten mengatakan bahwa setiap kontrak yang ditandatanganinya maka ia terikat dengan kontrak tersebut. ${ }^{37}$ Kalau pendapat ini yang digunakan bagaimana kalau perjanjian tersebut tidak dibubuhi tanda tangan? Seperti kontrak yang ada pada tiket pesawat. Pada dasarnya tidak ada ketentuan yang mengharuskan suatu kontrak itu ditandatangani, bahkan kontrak yang hanya disepakati dengan syarat saja sudah dapat dikatakan kontrak yang sah. ${ }^{38}$

Negara dengan sistem common law sebagaimana di Amerika berpandangan bahwa hakim di sana berpendapat bahwa kontrak baku (adhesi) tidak dapat diterapkan, hal ini disimpulkan oleh Whitman dan Gergacz. ${ }^{39}$ Walaupun demikian ini tidak berjalan lama. Pada tahun 1960-an pendapat ini mulai ditinggalkan. Hal ini ditandai dengan mulai diawasi penggunaan kontrak baku. ${ }^{40}$ Walaupun demikian mereka tetap berpegang teguh pada prinsip Cevat Emptor (Let the Buyer beware), yang berarti pembelilah yang harus hatihati. $^{41}$

${ }^{34}$ Sutan Remy Sjahdeini, Kebebasan Berkontrak dan Perlindungan yang Seimbang Bagi Para Pihak dalam Perjanjian Kredit Bank di Indonesia, h. 69.

${ }^{35}$ Sutan Remy Sjahdeini, Kebebasan Berkontrak dan Perlindungan yang Seimbang Bagi Para Pihak dalam Perjanjian Kredit Bank di Indonesia, h. 69.

${ }^{36}$ Sutan Remy Sjahdeini, Kebebasan Berkontrak dan Perlindungan yang Seimbang Bagi Para Pihak dalam Perjanjian Kredit Bank di Indonesia, h. 69.

${ }^{37}$ Sutan Remy Sjahdeini, Kebebasan Berkontrak dan Perlindungan yang Seimbang Bagi Para Pihak dalam Perjanjian Kredit Bank di Indonesia, h. 69.

${ }^{38}$ Munir Fuady, Hukum Kontrak (Dari Sudut Pandang Hukum Bisnis), Buku Kedua, h.92.

${ }^{39}$ Sutan Remy Sjahdeini, Kebebasan Berkontrak dan Perlindungan yang Seimbang Bagi Para Pihak dalam Perjanjian Kredit Bank di Indonesia, h. 70.

${ }^{40}$ Sutan Remy Sjahdeini, Kebebasan Berkontrak dan Perlindungan yang Seimbang Bagi Para Pihak dalam Perjanjian Kredit Bank di Indonesia, h. 70.

${ }^{41}$ Munir Fuady, Hukum Kontrak (Dari Sudut Pandang Hukum Bisnis), Buku Kedua, h.86.
Dalam konteks hukum Islam kontrak baku sebagai suatu perjanjian yang pengikat para pihak dianggap sah selama tidak ada melanggar ketentuan syariah lainnya. Selain karena ini sudah menjadi kebiasaan, hal ini juga agar mewujudkan efisiensi dalam melakukan transaksi. Islam tidak melarang kebiasaan selama kebiasaaan itu tidak melanggar ketentuan yang telah ditetapkan.

Perjanjian baku dalam Islam boleh digunakan dengan memperhatikan beberapa prinsip sebagai berikut: (a) prinsip kesepakatan; b. prinsip kesetaraan kewajiban dan hak. Prinsip ini berkaitan erat dengan keadilan dalam melakukan transaksi. Sebagaimana pendapat Murtadho Muthahari mengatakan bahwa keadilan itu bisa dilihat dari tiga makna. (1) keadilan berarti perimbangan atau keadaan seimbang, atau tidak pincang; (2) keadilan berarti persamaan, atau menghilangkan diskriminasi(3) keadilan berarti pemberian hak pribadi dan pemberian hak kepada siapa yang berhak; $;^{42}$ (c) prinsip bertanggung jawab. Prinsip bertanggung jawab di sini bukan hanya bertanggung jawab kepada sesama. Bertanggung jawab dalam ekonomi Islam lebih luas dari itu, yaitu bertanggung jawab kepada Allah Swt. yang telah memberikan amanah kepada manusia. Setiap transaksi yang kita lakukan tidak boleh bertentangan dengan aturan yang telah ditetapkan Allah. Prinsip ini lahir dari adanya nilai ketauhidan (pengesaan Allah Swt.); (d)prinsip iktikad baik; (e) prinsip sesuai dengan syariah; (f) prinsip adanya khiyâr. Prinsip ini tidak hanya sebagai alasan kebebasan berkontrak, tapi juga lebih luas dari itu. Prinsip ini mengandung arti bahwa perjanjian baku tersebut harus diserahkan terlebih dahulu kepada pihak konsumen yang menerima kontrak baku tersebut.

Kesepakatan dalam hukum Islam berawal dari pengakuan prinsip "an taradin" yaitu saling rida. Keridaan di sini tidak hanya dalam arti saling menyatakan "sepakat". ${ }^{43}$ Tapi perbuatan yang menunjukkan kesepakatan juga bisa dijadikan dasar adanya kesepakatan, selama isyarat tersebut tidak dilakukan dalam keadaan tidak sadar atau dalam keadaan paksaan.

Konteks Indonesia perjanjian baku belum diatur dalam peraturan khusus. Perjanjian baku tidak dilarang

${ }^{42}$ Eva Zulfa Nailufar, Pengupahan Berkeadilan Menurut Hukum Islam: Kajian UMP DKI, (Jakarta: A-Empat, 2014), h. 41.

43 Rahmawati, "Dinamika Akad Dalam Transaksi Ekonomi Syariah", dalam Jurnal al-Iqtishad, Jurnal Ilmu Ekonomi Syariah, Volume III, Nomor 1, Januari 2011. Baca juga perdebatan ulama terkait hal ini. Ibn Rusyd, Bidâyah al-Mujtahid wa Nihâyah al-Muqtashid, Cet. Ke-2. (Mesir: Maktabah al-Syurûq al-Dawlîyah, 2010), h. 511-514. 
dan juga tidak dianjurkan. Walaupun demikian perjanjian baku tetap diatur dalam Undang-undang Nomor 8 Tahun 1999 tentang Perlindungan Konsumen, Pasal 2.19 sampai dengan pasal 2.22 Priciples of international Commercial Contract (Prinsip UNIDROIT), dan Peraturan Otoritas Jasa Keungan Nomor: 1/POJK.07/2013.

\section{Aspek Hukum Perlindungan Konsumen dalam perjanjian baku menurut syariah}

Kelahiran UUPK adalah merespon semakin terjepitnya kedudukan konsumen dalam usaha yang sedang berkembang, kehadiran UU ini diharapkan mampu untuk mengurangi unfair bisnis and practice. ${ }^{44}$ Posisi yang berada di bawah dimanfaatkan untuk menekan dan mengambil keuntungan ekonomi. Perlindungan konsumen berdiri atas tiga asas umum yaitu: (1) asas kemanfaatan yang di dalamnya meliputi asas keamanan dan keselataman konsumen; (2) asas keadilan yang di dalamnya meliputi asas keseimbangan; dan (3) asas kepastian hukum. ${ }^{45}$

Pengelompokan ketiga asas di atas berdasarkan hukum ekonomi keadilan disejajarkan dengan asas keseimbangan, kemanfaatan disejajarkan dengan asas maksimalisasi, dan kepastian hukum disejajarkan dengan asas efisiensi. ${ }^{46}$ Ditambahkan lagi bahwa asas kepastian hukum disejajarkan dengan asas efisiensi kerena menurut Himawan "hukum yang berwibawa berarti hukum yang efisien, di bawah naungan mana seseorang dapat melaksanakan hak-haknya tanpa ketakutan dan melaksankan kewajibannya tanpa penyimpangan." ${ }^{47}$

Dengan asas-asas di atas diharapkan lahirnya UUPK ini mampu mencegah munculnya aktivitas-aktivitas bisnis yang mengarah pada unfair business and practice yang dengan cepat berkembang di tengah-tengah pasar bebas. ${ }^{48}$

Selain itu Lahirnya UUPK manfaatnya tidak hanya dirasakan oleh konsumen saja, sebagaimana dijelaskan di atas bahwa lahirnya UUPK memberikan pemahaman yang holistik tentang hak dan kewajibannya sebagai konsumen. Akan tetapi juga memberikan dampak

44 Iman Sjahputra, Perlindungan Konsumen dalam Transaksi Elektronik, (Bandung: PT. Alumni, 2010), h. 167.

45 Ahmadi Miru dan Sutarman Yodo, Hukum Perlindungan Konsumen, (Jakarta: PT. RajaGrafindo Persada, 2004), h. 26.

46 Ahmadi Miru dan Sutarman Yodo, Hukum Perlindungan Konsumen, (Jakarta: PT. RajaGrafindo Persada, 2004), h. 33.

47 Ahmadi Miru dan Sutarman Yodo, Hukum Perlindungan Konsumen, (Jakarta: PT. RajaGrafindo Persada, 2004), h. 33.

${ }^{48}$ Iman Sjahputra, Perlindungan Konsumen dalam Transaksi Elektronik, (Bandung: PT. Alumni, 2010), h. 167. yang positif kepada pelaku usaha, yang meningkatkan produktifitas dan kualitas produksi mereka, sehingga hak-hak konsumen dapat terpenuhi. ${ }^{49}$

Untuk mendukung tujuan tersebut OJK mengeluarkan peraturan tentang perlindungan konsumen yang berlaku khusus pada lembaga keuangan menambahkan lima prinsip. Kelima prinsip tersebut sebagai berikut: (1) transparansi; (2) perlakuan yang adil; (3) keandalan; (4) kerahasiaan dan keamanan data/ informasi konsumen; dan (5) penanganan pengaduan serta penyelesaian sengketa Konsumen secara sederhana, cepat, dan biaya terjangkau. ${ }^{50}$

Lebih lanjut POJK menjelaskan dalam pasal 4 UU bahwa OJK dibentuk dengan tujuan agar keseluruhan kegiatan jasa keuangan di dalam sektor jasa keuangan terselenggara secara teratur, adil, transparan, dan akuntabel, serta mampu mewujudkan sistem keuangan yang tumbuh secara berkelanjutan dan stabil, dan mampu melindungi kepentingan konsumen dan masyarakat.

UUPK telah memberikan rambu-rambu dalam pembuatan kontrak baku. Harus diakui bahwa posisi konsumen dalam kontrak baku hanya sebatas mengambil atau menolak polis yang ditawarkan kepadanya. Atas dasar itu pula negara sebagai pihak yang bertanggung jawab akan tegaknya perlindungan konsumen, sehingga kenyamanan dan keamanan dapat dirasakan oleh setiap konsumen.

Rentannya posisi konsumen untuk disalahgunakan POJK mengatur keseimbangan dalam perjanjian yang dibuat oleh perusahaan, asas ini dijelaskan dalam pasal 21. Keseimbangan ini ditujukan untuk meningkatkan rasa saling menghormati antara para pihak, serta melaksanakan kewajiban dan hak mereka secara seimbang, tanpa memberatkan satu pihak dan meringankan pihak lain.

Kebebasan dan kesepakatan dalam membuat kontrak adalah salah satu prinsip dalam membuat kontrak. Akan tetapi dengan adanya kontrak baku maka hal ini perlu diatur dalam peraturan perundangundangan. Untuk mengakomodasi hal tersebut UUPK dalam pasal 18 telah memberikan rambu-rambu dalam pembuatan kontrak baku. Ketentuan yang hampir sama juga diatur dalam pasal 22.

Dalam pasal 22 ayat (1) menegaskan kembali tentang pentingnya sebab yang halal sebagaimana dijelaskan

\footnotetext{
${ }^{49}$ Tatik Suryani, Perilaku Konsumen: Implikasi pada Strategi Pemasaran (Yogyakarta: Graha Ilmu, 2008), h. 332.

${ }^{50}$ Peraturan Otoritas Jasa Keuangan Nomor: 1/POJK.07/2013 tentang Perlindungan Konsumen Sektor Jasa Keuangan pasal 2.
} 
dalam pasal 1320. Sebab yang halal dalam pasal 1337 menjelaskan bahwa yang dimaksud dengan sebab yang halal adalah yang tidak bertentangan dengan peraturan perundang-undangan dan ketertiban umum. Poin tidak bertentangan dengan perundang-undangan inilah yang ditekankan dalam POJK tersebut.

Kemudian dalam ayat (3) dijelaskan hal-hal yang tidak boleh dicantumkan dalam kontrak baku sebagai berikut: (1) menyatakan pengalihan tanggung jawab atau kewajiban Pelaku Usaha Jasa Keuangan kepada Konsumen; (2) menyatakan bahwa Pelaku Usaha Jasa Keuangan berhak menolak pengembalian uang yang telah dibayar oleh Konsumen atas produk dan/atau layanan yang dibeli; (3) menyatakan pemberian kuasa dari Konsumen kepada Pelaku Usaha Jasa Keuangan, baik secara langsung maupun tidak langsung, untuk melakukan segala tindakan sepihak atas barang yang diagunkan oleh Konsumen, kecuali tindakan sepihak tersebut dilakukan berdasarkan peraturan perundang-undangan; (4) mengatur tentang kewajiban pembuktian oleh Konsumen, jika Pelaku Usaha Jasa Keuangan menyatakan bahwa hilangnya kegunaan produk dan/atau layanan yang dibeli oleh Konsumen, bukan merupakan tanggung jawab Pelaku Usaha Jasa Keuangan; (5) memberi hak kepada Pelaku Usaha Jasa Keuangan untuk mengurangi kegunaan produk dan/atau layanan atau mengurangi harta kekayaan Konsumen yang menjadi obyek perjanjian produk dan layanan; (6) menyatakan bahwa Konsumen tunduk pada peraturan baru, tambahan, lanjutan dan/atau perubahan yang dibuat secara sepihak oleh Pelaku Usaha Jasa Keuangan dalam masa Konsumen memanfaatkan produk dan/atau layanan yang dibelinya; dan/atau (7) Menyatakan bahwa Konsumen memberi kuasa kepada Pelaku Usaha Jasa Keuangan untuk pembebanan hak tanggungan, hak gadai, atau hak jaminan atas produk dan/atau layanan yang dibeli oleh Konsumen secara angsuran.

Untuk menjamin perlindungan konsumen dalam perspektif hukum Islam tidak hanya harus sesuai dengan perlindungan konsumen di atas. Perlu diperhatikan bahwa dalam teori akad, Islam menempatkan perlindungan hukum yang seimbang bagi para pihak. Bukan hanya konsumen sebagai penikmat dari produk yang dikeluarkan oleh perusahaan. Akan tetapi perlunya proses administrasi yang cepat, memaksa penggunaan kontrak baku.

Dalam konsep hukum Islam perlindungan konsumen selain yang tercantum pada hal-hal yang dilarang dalam akad, juga ada konsep yang dikenal dengan khiyâr. Konsep khiyâr sangat erat kaitanya dengan perlindung- an konsumen. Khiyâr memberikan kesempatan kepada pihak penerima untuk melakukan pilihan melanjutkan transaksi atau tidak.

Khiyâr dalam bahasa Arab berarti "pilihan". Secara terminologi Wahbah Zuhaili mendefenisikan khiyâr sebagai hak para pihak untuk melanjutkan akad atau tidak. $^{51}$ Khiyâr dapat kita bagi kedalam beberapa kategori. Pembagian yang umum dilakukan oleh ulama fikih adalah khiyâr 'ayb, khiyâr syarat dan khiyâr majlis.

Khiyâr 'ayb adalah pilihan kepada para pihak untuk melanjutkan atau tidak akad karena adanya kecatatan pada objek akad. Khiyâr 'ayb terjadi ketika pihak menemukan kecacatan terhadap objek yang diperjanjikan, walaupun telah terjadi serah terima. Pengakuan terhadap adanya aib terhadap barang yang diperjanjikan sesuai dengan kebiasaan 'urf.

Khiyâr syarath adalah hak pilih yang telah diperjanjikan sebelumnya oleh para pihak dalam jenjang waktu yang telah ditentukan. Kata syarat di sini menunjukkan bahwa kelangsungan perjanjian tersebut berhubungan dengan perjanjian dengan syarat yang mereka buat.

Sedangkan khiyâr majlis adalah hak untuk memilih untuk melanjutkan atau tidak transaksi pada waktu tawar menawar sedang berlangsung. Khiyâr ini biasanya dilakukan ketika kedua belah pihak bertemu dalam satu tempat.

Keberadaan khiyâr dalam transaksi ekonomi Islam dijamin dalam hadis Nabi Saw. sebagaimana yang diriwayatkan oleh Ibn Hibban dari Hakim bin Hazam:

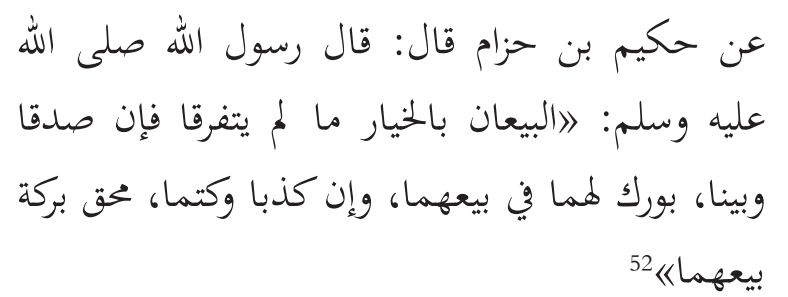

Hakim bin Hazam berkata, Rasulullah Saw. bersabda "orang yang melakukan jual beli terikat pada khiyâr selama mereka belum berpisah. Apabila mereka jujur dan transparan, jual beli mereka akan diberkahi Allah, akan tetapi kalau mereka berbohong dan tertutup ditarik keberkahan dari jual beli mereka. (HR. Ibn Hibban)

Terkait dengan kontrak baku dalam perspektif hukum islam, konsep khiyâr berperan penting dalam perjanjian baku. Harusnya perusahaan memberikan

أن يكون للمتعاقد الحق في إمضاء العقد أو فسخه : 51 Teks aslinya sebagai berikut Wahbah Musthafa al-Zuhaylî, al-fiqh al-Islâmî wa 'adillatuhu, Jilid 4, (Damaskus: Dâr al-Fikr, t.t.), h. 3104.

${ }^{52}$ Ibn Hibban, al-Ihsân fì taqrîb Shahîh Ibn Hibban, Jilid 11, Nomor Hadis 4904, (Beirut: Muassah Risâlah, 1988), h. 268. 
kesempatan kepada konsumen untuk mempelajari kontrak yang ada. Diperlukan waktu yang cukup untuk mempelajari hal tersebut. Sebelum dilakukan transaksi harus ada proses pembelajaran kepada para pihak untuk melanjutkan transaksi atau tidak.

Selain itu diperlukan pula pihak ketiga yang menjembatani para pihak ketika hak khiyâr semacam ini diperselisihkan. Penulis melihat bahwa hak khiyâr harus diterapkan pada setiap perjanjian yang telah dibuat oleh perusahaan. Sehingga tidak ada kesalah pahaman dari pihak konsumen. Pengaturan semacam ini belum terdapat dalam peraturan perundang-undangan yang ada.

\section{Penutup}

Menurut hukum Islam penggunaan kontrak baku tidak dilarang sebagaimana halnya juga dalam peraturan perundang-undangan tidak melarang menggunakan kontrak baku. menurut peraturan perundang-undangan kontrak baku dapat digunakan selama tidak melanggar UUPK pasal 18 dan juga POJK-PKSJK pasal 22. Dalam persfektif hukum Islam kontrak baku harus mencantumkan hal-hal yang telah difatwakan oleh DSN-MUI dan PMK Nomor 18/PMK.010/2010. Serta menjunjung tinggi asas kesetaraan dan keadilan.

Beberapa hak yang harus diatur secara tegas adalah: (1) pemberian kesempatan kepada para pihak untuk mempelajari isi perjanjian. Dalam hal ini konsumen harus diberikan waktu misalnya sampai tiga hari untuk mempelajari kontrak tersebut; (2) membuat standar baku yang harus ada dalam setiap kontrak dan skema yang seragam. Karena selama ini kontrak syariah berfariasi dan itu menyulitkan konsumen untuk memahami isi kontrak tersebut; (3) memberikan kesempatan kepada konsumen untuk melakukan komplen apabila hak-haknya dalam perjanjian tersebut dapat dirugikan oleh pihak perusahaan, serta mendirikan lembaga yang khusus menangani hal tersebut diluar perusahaan tersebut; Terakhir pemerintah harus segera membentuk undang-undang perjanjian sehingga perjanjian baku dapat diatur secara lengkap. Dana perlu pula pemerintah memasukkan konsep khiyâr dalam kebijakan pembentukan sebuah akad. Konsep ini bisa dikategorikan sebagai bagian dari usaha melindungi kepentingan pengusaha dan konsumen.[]

\section{Pustaka Acuan}

Amin, Mảruf, Fatwa Dalam Sistem hukum Islam, Cet. Ke-3, Jakarta: eLSAS, 2011.

Dewi, Gemala, Aspek Hukum dalam Perbankan dan
Perasuransian di Indonesia, Edisi Revisi cet. Ke-3, Jakarta: Kencana, 2006.

Dewi, Gemala, dkk, Hukum Perikatan Islam di Indonesia, Jakarta: Kencana, 2007.

Fadani, al-, Muhammad Yasin bin 'Isa, al-Fawaid alJaniyah, Beirut: Dar al-Mahjah al-Baidha, 2008.

Fatwa Dewan Syariah Nasional NO: 21/DSNMUI/X/2001, tentang Pedoman Umum Asuransi Syari'ah.

Fuady, Munir, Hukum Kontrak (Dari Sudut Pandang Hukum Bisnis), Buku Kedua, Jakarta: PT. Citra Aditya Bakti, 2003.

Ghazalî, al-, Abu Hamîd. al-Mustasfá, Beirut: Dâr alKutûb al-'Ilmîyah, $1413 \mathrm{H}$.

Halim, Abdul, Politik Hukum Islam di Indonesia: Kajian Posisi Hukum Islam dalam Politik Hukum Pemerintahan Orde Baru dan Era Reformasi, Jakarta: Badan Litbang dan Diklat Departemen Agama RI, 2008.

Haroen, Nasrun, Ushul Fiqh 1, cet. Ke-2, Jakarta: PT. Logos Wacana Ilmu, 1997.

Hibban, Ibn, al-Ihsân fî taqrîb Shahîh Ibn Hibban, Beirut: Muassah Risâlah, 1988. Jilid 11.

HS, Salim. dkk., Perancangan Kontrak dan Momerandum of Understanding (MoU), Jakarta: Sinar Grafika, 2007.

Jurnal Ahkam, Jurnal Ilmu Syariah, Vol. XI, No. 2, Juli 2012.

Jurnal al-Iqtishad, Jurnal Ilmu Ekonomi Syariah, Volume III, Nomor 1, Januari 2011.

Latif, AH. Azharudin, Fiqh Muamalat, Jakarta: UIN Jakarta Press: 2005.

Miru, Ahmadi, dan Sutarman Yodo, Hukum Perlindungan Konsumen, Jakarta: PT. Raja Grafindo Persada, 2004.

Muslehuddin, Muhammad, Filsafat Hukum Islam dan Pemikiran Orientalis: Studi Perbandingan Sistem Hukum Islam, terj. Yudian Wahyuni, Yogyakarta: Tiara Wacana Yogya, 1991.

Nailufar, Eva Zulfa, Pengupahan Berkeadilan Menurut Hukum Islam: Kajian UMP DKI, Jakarta: A-Empat, 2014.

Peraturan Otoritas Jasa Keuangan Nomor: 1/ POJK.07/2013 tentang Perlindungan Konsumen Sektor Jasa Keuangan pasal 2.

Rahman, Nandi, Asuransi Dalam Pandangan Islam, Jakarta: Lembaga Pers Bekasi, 2003.

Rusyd, Ibn, Bidâyah al-Mujtahid wa Nihâyah alMuqtashid, Cet. Ke-2, Mesir: Maktabah al-Syurûq al-Dawlîyah, 2010.

Sjahputra, Iman, Perlindungan Konsumen dalam Transaksi Elektronik, Bandung: PT. Alumni, 2010.

Subekti, hukum Perjanjian, Cet ke-19, Jakarta: Intermasa, 2002. 
Suryani, Tatik, Perilaku Konsumen: Implikasi pada Strategi Pemasaran, Yogyakarta: Graha Ilmu, 2008.

Sjahdeini, Sutan Remy, Kebebasan Berkontrak dan Perlindungan yang Seimbang Bagi Para Pihak dalam Perjanjian Kredit Bank di Indonesia, Jakarta: Institut Bankir Indonesia, 1992.
Syarifuddin, Amir, Meretas Kebekuan Ijtihad: Isu-isu Penting Hukum Islam Kontemporer di Indonesia, Cet. Ke-2, Jakarta: Ciputat Press, 2005.

Syarifuddin, Amir, Ushul Figh Jilid 2, Cet. Ke-2, Jakarta: PT. Logos Wacana Ilmu, 2001.

Zuhaylî, al-, Wahbah Musthafa, al-fiqh al-Islâmî wa 'adillatuhu, Damaskus: Dâr al-Fikr, t.t., Jilid 4. 